\title{
SUSTAINABILITY OF VIRTUAL COLLABORATIVE NETWORKS
}

\author{
Malgorzata Pankowska \\ University of Economics Katowice POLAND, pank@ae.katowice.pl
}

Sustainability exemplifies the new problem field for managers and project leaders in an emergent network-based organizational world where corporations must maintain consistency of purposes and yet be flexible enough to interact and compete in conditions of constant change and flux. The first part of the paper covers the theoretical framework of sustainability of collaborative networks as the simultaneous effort of balancing economic, social and intellectual development goals. The second part comprises the comparative analysis of 181 FP6 projects and the last part presents discussion on ways to increase sustainability.

\section{INTRODUCTION}

The etymology of "sustainable" carries interesting and important implications for the way the word is used as it includes several contradictions. The word "sustain" is derived form the Latin "sub-tenere", meaning "to uphold". This carries a passive connotation in it and gives the concept an image of stability, persistence and balance. "Sustainable" is used in a more active sense together with "development". Development means change, progress and growth. So, "sustainable development" can refer to a process which is being upheld or defended at the same time as it implies movement and improvement (Sunden \& Wicander, 2005). Sustainability and sustainable development are about actions, interactions, cooperation and collaboration in virtual collaborative networks developed as projects.

\section{THEORETICAL FRAMEWORK}

Sustainable development is the practice of meeting the needs of society today without compromising the ability of future generations to meet their own needs (Russell et al., 2007). Sustainability is a characteristic of a process or state that can be maintained indefinitely at a certain level. The term in its environmental usage, refers to the potential longevity of vital human ecological support systems, such as the planet's climatic system, systems of agriculture, industry, forestry and fisheries, and human communities in general and the various systems on which they depend.

Understanding sustainability is the simultaneous effort of balancing economic, social and environmental goals for a corporate (Bondy et al., 2007). As such, sustainability is another metaphor for describing corporate social responsibility, corporate citizenship or ethical business conduct and for the purpose of the paper sustainability is used as a synonym of these concepts. Sustainable business strategies and processes are roadmaps to achieve sustainability and it is about understanding and considering the positive and negative impacts and minimising the risk of unintended consequences across sustainability dimensions (Ahmed \& Sundaram, 2007). 
Models of governance for sustainability need to concentrate more on change than on stability, meaning the existing rules, customs, practices and rights are seen as the subject matter of governance to be influenced, rather than as the main business of governance (Martin et al., 2007). Governance refers to self-organizing of the interorganizational networks characterized by interdependence of resource exchange, business rules and significant autonomy from the state (Kjaer, 2007). Each virtual collaborative network develops their own intellectual resources and capabilities, but they alone do not ensure the sustainable advantage. A competitive advantage is sustainable when it persists despite efforts by competitors or potential entrants to duplicate or neutralize it. For this to occur, there must be persistent asymmetries among the networks. They must possess different resources and capabilities. Resource heterogeneity is the cornerstone of an important framework in strategy: the resource-based theory of the firm, which points out that if all firms in the market have the same stocks of resources and capabilities, no strategy for valuecreation is available to one firm that would not also be available to all other firms in the market. To be sustainable, competitive advantage must be followed by resources and capabilities that are scarce and imperfectly mobile (Besanko et al., 2007). Some resources are inherently nontradeable. These include the knowledge an organization has acquired through cumulative experience, or a reputation for toughness in its competition with rivals. Other resources may be tradeable, but because they are relationship specific, they may be far more valuable inside one organization than another. Business organizations implement different isolating mechanisms to ensure sustainability, which are generally divided into two distinguished groups i.e. impediments to imitation and early-mover advantages. Impediments to imitation include legal restrictions (patents, copyright protection, trademarks), governmental control over entry into markets (licensing, certifications) and favourable access to inputs by controlling sources of supply (ownership, long-term exclusive contracts). Early-movers advantages cover pioneers' abilities to cumulate experiences, develop reputation and generate network externalities more quickly than rivals.

\section{METHODOLOGY AND FINDINGS}

A collaborative network is constituted by a variety of entities (e.g. organizations and individuals) that are largely autonomous, geographically dispersed and heterogeneous in terms of their operating environment, culture, social capital and goals. According to Camarinha-Matos et al. sustainable development of collaborative networks needs to be supported by fundamental research leading to the establishment of collaborative networks as a new scientific discipline (2005).

Virtual organizations are temporary alliances of organizations that come together to share skills or core competencies and resources in order to better respond to business opportunities and produce value-added services in computer supported environment. This temporality is not contradictive to sustainability. The main problem of this paper is to explain how virtual collaborative networks prolong and could prolong their vitality and sustainability. Post-modern virtual organizations move beyond the bureaucratic and hierarchical form of organizing. There is no assumption that they consist of a stable set of structures and rules, but quite the opposite. They are an emergent, semantically constructed phenomena consisting of evolving networks of actors (Rasche, 2008). 
In each virtual organization project, sponsors expect long-time results that would constitute knowledge and social capital. They want to know, what results will be achievable in the future after finishing the project and how project partners wish to ensure the results' sustainability. In this research, the FP6 participating organizations are evaluated from the point of their convincing commitment towards a deep and durable integration beyond the period of EC support. In FP6 traditional funding instruments of the scientific research community such as Specific Targeted Research Projects (STREPs), Coordination Actions (CAs), Specific Support Actions (SSAs) were implemented as well as more ambitious projects i.e. Integrated Projects (IPs) and the Networks of Excellence (NoE) (table 1).

Table1 - The Sixth Framework Programme (FP6) Instruments

\begin{tabular}{|c|c|c|c|c|c|c|}
\hline $\begin{array}{c}\text { Instru- } \\
\text { ment }\end{array}$ & Purpose & $\begin{array}{c}\text { Target } \\
\text { Audience }\end{array}$ & $\begin{array}{c}\text { EU covered } \\
\text { activities }\end{array}$ & $\begin{array}{l}\text { Average } \\
\text { duration }\end{array}$ & Flexibility & $\begin{array}{c}\text { Partnerships } \\
\text { increase }\end{array}$ \\
\hline IPs & $\begin{array}{c}\text { objective- } \\
\text { driven research, } \\
\text { sustainable } \\
\text { development }\end{array}$ & $\begin{array}{c}\text { industry, } \\
\text { SMEs, } \\
\text { universities, } \\
\text { potential end } \\
\text { users }\end{array}$ & $\begin{array}{c}\text { research, } \\
\text { demonstrations, } \\
\text { training, } \\
\text { management }\end{array}$ & $36-60$ & $\begin{array}{c}\text { yearly } \\
\text { update of } \\
\text { work plan }\end{array}$ & $\begin{array}{c}\text { possible } \\
\text { through } \\
\text { competitive } \\
\text { calls }\end{array}$ \\
\hline STREPS & $\begin{array}{l}\text { objective - } \\
\text { driven } \\
\text { research, } \\
\text { focused on a } \\
\text { simple issue }\end{array}$ & \begin{tabular}{|l} 
industry, \\
SMEs, \\
universities, \\
research \\
institutes \\
\end{tabular} & $\begin{array}{c}\text { research, } \\
\text { demonstrations } \\
\text { innovation based } \\
\text { activities, } \\
\text { management }\end{array}$ & $18-36$ & $\begin{array}{l}\text { fixed over } \\
\text { all work } \\
\text { plan }\end{array}$ & possible \\
\hline $\mathrm{NoE}$ & $\begin{array}{c}\text { durable } \\
\text { integration of } \\
\text { the partners, } \\
\text { research } \\
\text { activities, } \\
\text { sustainable } \\
\text { development }\end{array}$ & $\begin{array}{l}\text { industry, } \\
\text { SMEs, } \\
\text { universities, } \\
\text { research } \\
\text { institutes }\end{array}$ & \begin{tabular}{|c} 
Joint Programme \\
of Activities (JPA) \\
integration, joint \\
research, \\
spreading of \\
excellence, \\
management
\end{tabular} & $48-60$ & $\begin{array}{c}\text { yearly } \\
\text { update of } \\
\text { work plan }\end{array}$ & $\begin{array}{c}\text { possible } \\
\text { through } \\
\text { competitive } \\
\text { calls }\end{array}$ \\
\hline CAs & $\begin{array}{c}\text { coordination } \\
\text { networking }\end{array}$ & \begin{tabular}{|} 
industry, \\
SMEs, \\
universities, \\
research \\
institutes
\end{tabular} & $\begin{array}{c}\text { research meeting } \\
\text { coordination, } \\
\text { events, } \\
\text { dissemination, } \\
\text { management }\end{array}$ & $18-36$ & $\begin{array}{l}\text { fixed over } \\
\text { all work } \\
\text { plan }\end{array}$ & possible \\
\hline SSAs & $\begin{array}{l}\text { preparation of } \\
\text { the future } \\
\text { action, support } \\
\text { policies, } \\
\text { results } \\
\text { dissemination } \\
\end{array}$ & $\begin{array}{l}\text { industry, } \\
\text { SMEs, } \\
\text { universities, } \\
\text { research } \\
\text { institutes }\end{array}$ & $\begin{array}{c}\text { meetings, } \\
\text { workshop studies, } \\
\text { publications, } \\
\text { awards, } \\
\text { management }\end{array}$ & $9-30$ & $\begin{array}{c}\text { fixed over } \\
\text { all work } \\
\text { plan }\end{array}$ & possible \\
\hline
\end{tabular}

Source: (Classification of the FP6 instruments, 2004)

Particularly, for NoE and IPs, the scope and degree of the effort to achieve integration and the network's capacity to promote excellences beyond its membership, as well as the prospects of the durable integration of their research capabilities and resources after the end of the periods covered by the EC financial contribution are important (table 1). This is to be achieved through the implementation of a Joint Programme of Activities (JPA) aimed principally at creating a progressive and durable integration of the research capacities of the network partners while, at the same time, advancing knowledge on the topic.

To identify the existing practices of virtual collaborative networks sustainability a comparative analysis was set up for a group of 181 networks (Food, 2007). The projects were funded within FP6 TP5 Food Quality and Safety and drew on 
expertise from such areas as genomics, medicine, information technologies, ethics, environmental, economic and social sciences to achieve their aims. A total of $€ 751$ million in funding was injected in research activities in 2002-2006. The supported research activities contributed to the realisation of European Research Area promoting mobility, cooperation and training of scientists and practitioners through the pooling of know-how and expertise.

All the involved networks identified the need for sustainability assurance, but they had very differently implemented practices to deal it and similar actions planned. Many organizations had practices for systematic collection and saving of experience, but also some of them had informal, verbal exchange of experience between managers of similar networks. Some partners measured their performance during the project for the use of management. In some cases the customer required the recording of quality data. In this comparative analysis the following criteria have been accepted:

- Publications: scientific papers, news, newsletters, lay papers

- Links to related projects, other networks and organizations

- Access to the network for partners, registered users and open for all

- Events

- Access to knowledge base

- Surveys and questionnaires for customers

- Training and courses offline and online

- Jobs offers and scholarships.

Table 2 - FP6 TP5 Food Quality and Safety projects in numbers according to comparative criteria

\begin{tabular}{|c|c|c|c|c|c|c|c|c|c|}
\hline & $\begin{array}{l}\text { Publi- } \\
\text { cations }\end{array}$ & Links & $\begin{array}{l}\text { Only for } \\
\text { partners } \\
\text { network }\end{array}$ & $\begin{array}{c}\text { Open } \\
\text { network }\end{array}$ & Events & $\begin{array}{c}\text { Know- } \\
\text { ledge } \\
\text { base }\end{array}$ & Surveys & $\begin{array}{c}\text { Train- } \\
\text { ings }\end{array}$ & $\begin{array}{c}\text { Jobs } \\
\text { offers }\end{array}$ \\
\hline $\begin{array}{c}\text { STREPs } \\
\text { (total 59) }\end{array}$ & 26 & 7 & 12 & 2 & 21 & 4 & 4 & - & 1 \\
\hline $\begin{array}{c}\text { NoE } \\
\text { total 12) }\end{array}$ & 12 & 7 & 4 & 3 & 12 & 2 & 2 & 8 & 7 \\
\hline $\begin{array}{c}\text { CAs } \\
\text { total 7) }\end{array}$ & 3 & 1 & - & 1 & 3 & - & 1 & - & - \\
\hline $\begin{array}{c}\text { IPs } \\
\text { total 31) }\end{array}$ & 31 & 15 & 13 & 8 & 31 & 9 & 6 & 8 & 7 \\
\hline $\begin{array}{c}\text { SSAs } \\
\text { total 72) }\end{array}$ & 37 & 15 & 12 & 22 & 48 & 22 & 6 & 2 & 6 \\
\hline
\end{tabular}

Experiences were shared in the networks most often through different events: cooperation meetings, workshops, conferences, symposia, congresses, discussion forums, seminars, exhibitions, training and mobility programmes, board meetings of partly business and partly social character. These can be used to share knowledge, to introduce new members, present the latest news and to discuss ideas for development. Generally, although the projects were funded in 2002-2006, many have still not developed a website or it has been removed and was not placed in the catalogue "Food Quality and Safety" (i.e. 63 out of all).

The 59 STREPs (33\%) were designed to gain knowledge or demonstrate the feasibility of new technologies. Available to small and emerging players, they fulfilled an important function for the scientific community, because they financed research on new technologies that do not necessarily have a direct impact on the 
market. The project partners are involved in realizing from-fork-to-farm strategy to ensure the purity at every stage of the production process, thereby promoting high quality European products on a sustainable basis (e.g. BEESHOP project). STREPs also helped to create recommendations for lifestyles and healthy habits to improve the quality of life of EU citizens. They communicate project results through publications, different events and in closed communities. The REPRO project ensures direct public dissemination and development of three stakeholder integration platforms: an industrial interaction platform, a consumer integration platform and a co-producent brokerage platform. The STREPs: Qalibra and Beneris were revealed as connected complementary projects financed simultaneously. IRRQUAL project on irrigation model development was observed to declare no need to launch virtual network.

The 7 CAs (4\%) covered the definition, organization and management of joint initiatives that aimed to avoid duplication of efforts in different countries and sought to build synergies between existing national and international initiatives so as to better integrate European research. Only some of them were involved in publications and events, there was no need for open trainings, staff mobility and exchange of knowledge in closed community.

The 72 SSAs (39\%) helped to prepare and support new research activities, so they are not included in Table 2 as not having specified project theme. They aided in the preparation of FP7, encouraging and facilitating participation in European collaborative research efforts. In particular, FP6 Specific Support Actions were directed at the following seven objectives: achieving ERA objectives, promotion of SME participation, stimulating international cooperation, linking with candidate countries, supporting policy development, stimulating exploitation, and contributing to the EU strategy for life sciences and biotechnology. SSAs are involved in developing closed virtual networks (12 projects) as well as open networks (22 projects) (Table 3). The BIOPOP SSAs project sets up a website featuring a virtual city square to promote further public participation in science. Science agora is open to the public to participate in and comment on. There are music games, animations and genetic toys for young children. The DIVERSEEDS SSAs project aims at establishing a communication platform that makes it possible for European researchers and their Asian counterparts to exchange the results of their research. The authorized access pages provide the project information in Wiki format. The ETNA SSAs project builds a network of researchers all over Europe including third countries. The created virtual collaborative network ensures continuous interactions among scientists, research organizations and research programmes. The GMOCOMPASS SSAs project aims to study genetically modified organisms (GMOs) and to establish a European consumer-oriented website providing easy-to-understand information on the safety of GMOs products. The GMO-COMPASS partners develop marketing strategies (offline and online) such as content cooperation with consumer and commercial food-related websites and consumer websites, offering news, interviews, fact sheets, forums, virtual platforms for open dialogues, moderated online discussions to address risk perceptions and consumer expectations on food quality and the safety of GMOs products. The SAFOODNET SSAs project is to preserve the integrity of the food safety area, building a sustainable network promoting the sharing of knowledge in order to prevent risk and develop pilot actions, seminars, regional meetings and local presentations. The FUNCTIONALFOODNET SSAs project is divided into 2 sub-networks: general 
network and product-specific network to support cooperation among SMEs and strong companies to support healthy food production and advertising. The EPIPAGRI SSAs project declares the feasibility for joint management of the intellectual property of European PROs (Public Research Organizations) to bring them together and to unify for a strategy of raising interest in a European initiative for harmonizing public intellectual property right policies. The aim is to design guidelines concerning research partnership agreements and licensing policies.

The 31 IPs (17\%) were designed to deliver new knowledge, a competitive advantage to European industry, and respond to SME needs by integrating and mobilising the critical mass and research activities and resources. In IPs conferences, country reports, international correspondent networks reporting on progress, annual meetings and workshops, forums, reportages and interviews from the laboratory and the field, insights into projects aims and methods of research are applied (i.e. CO-EXTRA project). The EUROPREVALL IP is to explain the demographic patterns for allergies, so the project publications for people without scientific background (lay state-of-the-art papers) as well as review papers and academic position papers are accessible on the IP website.

The 12 NoE projects $(7 \%)$ were aimed at strengthening excellence by connecting resources and expertise and supporting effective integration and cooperation in the research activities of the network partners, as well as advancing the overall topics of interest. Their proposition is to reach a durable restructuring and shaping and integration of efforts and institutions or parts of institutions, the success of a NoE is not measured in terms of scientific results but by the extent to which the social fabric for researchers and research institutions in a given field has changed due to the project, and the extent to which the existing capacities become more competitive as a result of this change. Interacting activities include coordinated programming of the partner's activities, sharing of research platforms, tools and facilities, joint management of the knowledge portfolio, staff mobility and exchanges, relocation of staff, teams and equipment, reinforcement of electronic communication systems. The sustainability of the NoE is to be achieved at three different levels of partnership i.e. policy, research and dissemination.

For example, EAPGENE NoE accepts spreading of excellence through trainings, technology transfer and knowledge dissemination to the third countries, cross linking with other collaborative networks, ethics and consumer concerns development, evaluation of public concerns and requests, communications through the website for public and for partners, conferences, workshops, newsletters and leaflets. They offer mobility opportunities and links to Knowledge Database Wiki. The objective of EADGENE is to develop the ATO (animal trait ontology) and to develop future projects to increase the value of an ATO for the animal production industry and research. The EPIZONE NoE consortium agreement defines the development of a management structure based on a virtual institute with clear rules and processes, including mechanism for review and assessment and an appropriate administrative support. The virtual institute activities cover diagnostics, intervention strategies, surveillance, epistemology and risk assessment. In ENDURE NoE a virtual laboratory named the European Pest Control Competence Centre was created as a source of knowledge and expertise for supporting public policy makers, regulatory bodies, extension services and other ways to protect stakeholders. 


\section{SUSTAINABILITY FRAMEWORK}

The FP6 guides for applicants do not directly specify how sustainability must be expressed and measured in projects. Evaluation criteria for the projects cover proposal relevance to the objectives of co-operative research, science and technology excellence, potential impact, excellence of the consortium, quality of management, mobilisation of resources (Horizontal, 2003). Each of these criteria concerns sustainability assurance, so the important problem of sustainability is usually addressed in project work packages. Project stakeholders are demanded to reveal if the project demonstrates the effective plan for spreading excellence, exploitating results and disseminating knowledge, including SMEs and organizations outside the collaborative network

This chapter proposes a normative framework for judging the sustainability effects and makes suggestion on how to create virtual network capable of offering a sustainability contribution. The sustainability model integrates the informational, social and economic dimensions of business that helps to understand the complexities and impact of sustainability issues (Table 3).

Table 3 - Sustainability dimensions

\begin{tabular}{|c|l|}
\hline $\begin{array}{c}\text { Sustainability } \\
\text { dimension }\end{array}$ & \multicolumn{1}{|c|}{ Item description } \\
\hline $\begin{array}{c}\text { Virtual collaborative } \\
\text { network project strategy }\end{array}$ & $\begin{array}{l}\text { Specification of what, for what needs, why, where, when and how } \\
\text { project stakeholders want to achieve in the long run }\end{array}$ \\
\hline $\begin{array}{c}\text { Wide participation and } \\
\text { clear, shared purpose }\end{array}$ & $\begin{array}{l}\text { Development of abundant, long-term, mutually beneficial, collaborative } \\
\text { relationships and a shared project vision among partners }\end{array}$ \\
\hline $\begin{array}{c}\text { Information publicly } \\
\text { available and used to } \\
\text { improve program and } \\
\text { reward effort }\end{array}$ & $\begin{array}{l}\text { Dissemination of information on project results in open networks to } \\
\text { determine if activities are worth sustaining, continuous updating and } \\
\text { rewards from the customer's point of view }\end{array}$ \\
\hline $\begin{array}{c}\text { Science and technology } \\
\text { resources }\end{array}$ & $\begin{array}{l}\text { Obtaining and utilization of technology, material, personnel resources } \\
\text { through products commercialisation or continuous sponsoring }\end{array}$ \\
\hline $\begin{array}{c}\text { Collaborative } \\
\text { complementary skills, } \\
\text { knowledge, training and } \\
\text { mobility opportunities }\end{array}$ & $\begin{array}{l}\text { Self-organization and self-stimulation to further research as well as } \\
\text { continuous upgrading project knowledge involving both internal partners } \\
\text { and external organizations in order to institutionalize research programs. } \\
\text { Sharing knowledge resources with IPR respect }\end{array}$ \\
\hline $\begin{array}{c}\text { Decision-making } \\
\text { distributed power }\end{array}$ & $\begin{array}{l}\text { Development of wide participation in project management, judicious } \\
\text { delegation of power to promote ownership }\end{array}$ \\
\hline $\begin{array}{c}\text { Coordination with } \\
\text { current EU science and } \\
\text { research policies }\end{array}$ & $\begin{array}{l}\text { Fitting the project into research policy goals and initiatives. Usage of } \\
\text { existing institutional processes to meet the project needs }\end{array}$ \\
\hline $\begin{array}{c}\text { Promotion and } \\
\text { marketing }\end{array}$ & $\begin{array}{l}\text { Market the project's value, target resources and apply agile methods of } \\
\text { project management to help the project be flexible, hold out in lean } \\
\text { times, and take advantages of unexpected opportunities }\end{array}$ \\
\hline
\end{tabular}

Modelling these sustainability dimensions is not simple, as they do not have equal weights in the decision-making and operational processes. Modelling each dimension separately does not properly address sustainable development issues as they are interrelated and any change in one dimension influences the others. Modern virtual collaborative network are constantly emerging. They are autopoietic, not in the sense that they do not receive inputs from the environment, but rather that they are self-steering. They steer the inputs in directions they determine themselves in strategy vision. This autopoiesis is to ensure their sustainability. Agile project management support post-modern development of virtual networks, particularly 
continuous innovativeness, and iterative approach to project implementation, delivering the project results adaptable to customer requirements and in the reliable way.

\section{CONCLUSIONS}

High quality food production and distribution, GMOs products risks, allergies, adequate nutrition are problems important for all people, so the FP6 TP5 Food Quality and Safety projects results have a wide spectrum of recipients. FP6 instruments enable financial support to develop closed or open collaborative networks. In presented in paper projects, the virtual collaboration was utilized to generate knowledge (included in knowledge bases and publications) and social capital (through links and partner relationships) and this way to ensure virtual network's sustainability. The sustainability as qualitative feature must be measured multi-dimensionally.

\section{REFERENCES}

1. Ahmed M.D. Sundaram D. A Framework for Sustainability Decision Making System: A Proposal and an Implementation, ICDSS 2007 Decision Support for Global Enterprises, Kapartji S (ed.) http://www.cba.uni.edu/ICDSS2007/

2. Besanko D., Dranove D., Shanley M., Schaefer S. Economics of Strategy, J.Wiley \& Sons. London, 2007

3. Bondy K., Matten D., Moon J. "Codes of conduct as a tool for sustainable governance in MNCs". In Corporate governance and sustainability, Benn S. Dunphy D. (eds.) London, Routledge, 2007

4. Camarinha-Matos L.M., Afsarmanesh H., Ollus M.: ECOLEAD: A holistic approach to creation and management of dynamic virtual organizations. Collaborative Networks and Their Breeding Environments, Camarinha-Matos L.M., Afsarmanesh H., Ortiz A (eds.) Springer, NY. 2005, 3-17.

5. Classification of the FP6 instruments, October, 2004, http://cordis.europa.eu/fp6/instruments.htm

6. Food Quality and Safety in Europe, Project Catalogue, European Commission, Brussels, December 2007, http://ec.europa.eu/research/biosociety/food quality/download_en.html

7. Horizontal Research Activities Involving SMEs, The FP6 Integrating and Strengthening the European Research Area, Brussels, 2003, http://cordis.europa.eu/fp6/instruments.htm

8. Kjaer M., Governance, Cambridge, Polity Press, 2004

9. Martin A., Benn S., Dunphy D. Towards a model of governance for sustainability. In Corporate governance and sustainability, Benn S., Dunphy D. (eds.) London, Routledge, 2007

10. Rasche A. The Paradoxical Foundation of Strategic Management, Physica-Verlag, A Springer company, Heidelberg, 2008

11. Russell S., Haigh N., Griffiths A. "Understanding corporate sustainability". In Corporate governance and sustainability, Benn S., Dunphy D. (eds.), London, Routledge, 2007

12. Sunden S., Wicander G. ICT in Developing Countries: to Be Sustainable or Not - Is That the Question? ISD'2005 Proceedings of the Fourteenth International Conference on Information Systems Development: Pre-Conference, 14-17 August 2005, Karlstad, Sweden, 103-115. 